\title{
PERENNIAL HERBACEOUS LEGUMES AS LIVE SOIL MULCHES AND THEIR EFFECTS ON C, N AND P OF THE MICROBIAL BIOMASS
} \author{
De-Polli2; Marcelo Grandi Teixeira² \\ ${ }^{1}$ Depto. de Solos e Geologia - ESAM, C.P. 137 - CEP: 59625-900 - Mossoró, RN. \\ ${ }^{2}$ Embrapa Agrobiologia - CEP:23890-000 - Seropédica, RJ. \\ ${ }^{3}$. Alvarez de Azevedo, 242/602 - CEP: 24220-051 - Icarai - Niteroi, RJ. \\ *Corresponding author <gpduda@bol.com.br>
}

Gustavo Pereira Duda ${ }^{1 *}$; José Guilherme Marinho Guerra²; Marcela Teixeira Monteiro3; Helvécio

\begin{abstract}
The use of living mulch with legumes is increasing but the impact of this management technique on the soil microbial pool is not well known. In this work, the effect of different live mulches was evaluated in relation to the $\mathrm{C}, \mathrm{N}$ and $\mathrm{P}$ pools of the microbial biomass, in a Typic Alfisol of Seropédica, RJ, Brazil. The field experiment was divided in two parts: the first, consisted of treatments set in a $2 \times 2 \times 4$ factorial combination of the following factors: live mulch species (Arachis pintoi and Macroptilium atropurpureum), vegetation management after cutting (leaving residue as a mulch or residue remotion from the plots) and four soil depths. The second part had treatments set in a $4 \times 2 \times 2$ factorial combination of the following factors: absence of live mulch, $A$. pintoi, Pueraria phaseoloides, and $M$. atropurpureum, $\mathrm{P}$ levels $\left(0\right.$ and $\left.88 \mathrm{~kg} \mathrm{ha}^{-1}\right)$ and vegetation management after cutting. Variation of microbial $C$ was not observed in relation to soil depth. However, the amount of microbial $P$ and $\mathrm{N}$, water soluble $\mathrm{C}$, available $\mathrm{C}$, and mineralizable $\mathrm{C}$ decreased with soil depth. Among the tested legumes, Arachis pintoipromoted an increase of microbial $\mathrm{C}$ and available $\mathrm{C}$ content of the soil, when compared to the other legume species ( Pueraria phaseoloides and Macroptilium atropurpureum). Keeping the shoot as a mulch promoted an increase on soil content of microbial $\mathrm{C}$ and $\mathrm{N}$, total organic $\mathrm{C}$ and $\mathrm{N}$, and organic $\mathrm{C}$ fractions, indicating the importance of this practice to improve soil fertility.
\end{abstract}

Key words: microbial phosphorus, manure green, nutrients cycling

\section{LEGUMINOSAS HERBÁCEAS PERENES COMO COBERTURA VIVA DO SOLO E SEU EFEITO NO C, N E P DA BIOMASSA MICROBIANA}

\begin{abstract}
RESUMO: A adoção de práticas de cobertura do solo com leguminosas tem aumentado. Porém, o impacto desta prática sobre o compartimento microbiano ainda não é bem conhecido. Para avaliar o efeito de diferentes leguminosas, sobre o C, $\mathrm{NeP}$ da biomassa microbiana, coletaram-se amostras de Argissolo oriundas de um experimento sob condições de campo em Seropédica-RJ. O experimento foi subdividido em dois ensaios. No primeiro, os tratamentos corresponderam à combinação de três fatores: espécie de cobertura viva (Arachis pintoi e Macroptilium atropurpurem), manutenção em cobertura ou remoção dos resíduos após o corte e profundidade de coleta do solo. No segundo ensaio, os tratamentos corresponderam à combinação de três fatores: ausência de cobertura viva, $A$. pintoi, Pueraria phaseoloides e $M$. atropurpureum, doses de $\mathrm{P}(0$ e 88 $\mathrm{kg} \mathrm{ha}^{-1}$ ) e manejo dos resíduos da parte aérea das plantas. Não houve variação do $\mathrm{C}$ microbiano com a profundidade do solo. Porém, para o $\mathrm{P}$ e N microbianos, C orgânico do solo, C solúvel em água, disponível e mineralizável, o aumento da profundidade proporcionou diminuição destas características. As leguminosas usadas influenciaram de maneira diferenciada as variáveis analisadas. $O A$. pintoi promoveu elevação nos teores de $\mathrm{C}$ microbiano e disponível, comparativamente as demais espécies utilizadas ( $P$. phaseoloides e $M$. atropurpureum). A manutenção dos resíduos das leguminosas após cada corte promoveu aumentos nos teores de $\mathrm{C}$ e $\mathrm{N}$ microbianos, $\mathrm{C}$ orgânico e $\mathrm{N}$ total e frações de $\mathrm{C}$ orgânico do solo enfatizando a importância de utilização desta prática para melhorar a fertilidade do solo.

Palavras-chave: fósforo microbiano, adubo verde, ciclagem de nutrientes
\end{abstract}

\section{INTRODUCTION}

The utilization of perennial herbaceous legumes as live mulches for the soil in orchards is expanding. The benefits of this practice with regard to soil protection and incorporation of organic matter were discussed by Monegat, (1991). Among them, protection against the process of erosion, decreased impact of raindrops and water run-off, potential improvement in structure and decreased tillage operations can be pointed out as the main. Live mulching favors the process of nutrient cycling, weed control, and microorganism activity in the soil, among others. Even though different plant families can be used for this purpose, the legumes are important since they can supply nitrogen by means of biological fixation of $\mathrm{N}$ from the atmosphere (Monegat, 1991).

The impact of live mulches on soil characteristics is still not known in detail. The incorporation of organic 
matter and the consequent soil enrichment could be a criterion for this. However, the great amount and variability in soil organic matter make its use as a quality indicator not very appropriate or insufficient, since the short-term variations that occur in the soil environment are not readily accompanied by the changes in total organic matter (Liang et al., 1998). In addition, the dynamics of the total organic compartment of the soil is slow, which does not happen with the more labile compartments (Sparling et al., 1998).

Conversely, the soil microbial biomass (SMB) has been utilized as a sensitive indicator of variations in soil organic matter (Costantini et al., 1995; Werner, 1997) as a result of modifications caused by agricultural practices such as the addition of manure (Simek et al., 1999), and crop rotation (Linn \& Doran, 1984; Anderson \& Domsch, 1989; Insan et al., 1991; Ladd et al., 1994). SMB has also been utilized to compare soil tillage systems, like no-till in relation to conventional planting (Vargas \& Scholles, 1998) and soil organic management as compared to conventional management (Reganold, 1988; Werner, 1997; Swezey et al., 1998), where higher values of microbial biomass were observed in systems that incorporate and maintain more organic residues in the soil (Granatstein et al., 1987; Character, 1991).

SMB is crucial, since it is the compartment responsible for transforming soil organic matter, and for nutrient cycling, in addition to representing a potential source of $\mathrm{N}$ and $\mathrm{P}$, among other nutrients (De-Polli \& Guerra, 1999). For this reason, SMB is the active fraction of soil organic matter, as it governs the nutrient dynamics in the soil, sometimes acting as a mineralization agent, sometimes as an immobilization agent, increasing or decreasing the availability of nutrients for the plants.

Even though the process of immobilization is sometimes considered as a negative aspect, under certain situations it could be interesting, since it is a temporary process, and, therefore, it consists in a potential reservoir of nutrients for the plants (Paul \& Clark, 1996).

Even though the microbial biomass can be used as an index for evaluation of the impact of soil management practices, other characteristics can be evaluated. Thus, the utilization of labile fractions of organic carbon in the soil, that are simpler to be determined, can be useful in the evaluation of modifications in soil quality, as suggested by some authors (Liang et al., 1998; Sparling et al., 1998). Water soluble carbon, for example, is made up of easily degradable compounds, which show strong correlation with microbial carbon (Liang et al., 1996; Liang et al., 1998). Duda et al. (1999) utilized water soluble carbon and other fractions of organic carbon such as the carbon in saline solution, mineralizable carbon and light organic matter, for characterizing degraded areas, and concluded that these fractions were useful to distinguish degraded from non-degraded areas.
Some reports have stressed the edaphic and climatic adaptability and productivity of ground cover plants (Dalcomo, 1997). Others evaluate the production of plant mass, speed of covering, and competitiveness of the cover plant relative to the economic crop (Guerra \& Teixeira, 1997; Perin et al., 1998; Espíndola et al., 1998a). However, the impact on the microbial compartment and carbon fractions in the soil has been so far overlooked.

Thus, the objective of this paper was to evaluate the effect of different perennial herbaceous legume species, submitted to phosphate fertilization, on $\mathrm{C}, \mathrm{N}$ and $\mathrm{P}$ of the microbial biomass and organic carbon fractions of an Argisol.

\section{MATERIAL AND METHODS}

Field soil samples were collected in February,

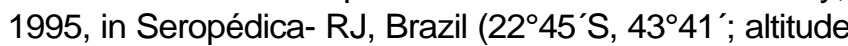
$33 \mathrm{~m})$. The soil was classified as a Typic Afisol, having the following chemical characteristics: $\mathrm{pH}$ in water (5.6); $\mathrm{P}\left(2.0 \mathrm{mg} \mathrm{kg}^{-1}\right) ; \mathrm{K}\left(1.8 \mathrm{mmol}_{\mathrm{cm}} \mathrm{dm}^{-3}\right) ; \mathrm{Ca}+\mathrm{Mg}(44.0 \mathrm{mmol}$ $\left.\mathrm{dm}^{-3}\right) \mathrm{Ca}\left(30 \mathrm{mmol}_{\mathrm{C}} \mathrm{dm}^{-3}\right)$ and $\mathrm{Al}\left(0.0 \mathrm{mmol}_{\mathrm{c}} \mathrm{dm}^{-3}\right)$.

The experiment was divided into two assays, using as a reference the original statistical design, in random blocks, organized as a $5 \times 4$ factorial array, with three replicates. Treatments consisted of five perennial herbaceous legume species: (Calopogonium mucunoides - calopa, Macroptilium atropurpureum - siratro, Pueraria phaseoloides - Kudzu, Stylosanthes guianensis - stylo and Arachis pintoi - forage peanut) and sources and rates of phosphorus (control - no phosphate fertilization; 44 and $88 \mathrm{~kg} \mathrm{P} \mathrm{ha}^{-1}$ in the form of Araxá rock phosphate and 44 $\mathrm{kg} \mathrm{ha}^{-1} \mathrm{P}$ in the form of triple superphosphate). After the first cutting of the aerial part of the plants (approximately five months after planting, except for $A$. pintoi, which was replanted and not cut ten months after installing the experiment) a new factor was introduced, based on splitting the plots, which consisted in maintaining the plots covered, or removing, the residues of the aerial parts of the plants after each cut.

In the first assay, treatments corresponded to the combination of the following factors: live mulch species (A. pintoi and M. atropurpureum), residue management (maintaining covered or removing residues after cutting) and soil collecting depths $(0-2.5 ; 2.5-5.0 ; 5.0-10.0$ and $10.0-20.0 \mathrm{~cm}$ ). The soil samples were removed from the experimental units, which were submitted to phosphate fertilization at the rate of $88 \mathrm{~kg} \mathrm{ha}^{-1} \mathrm{P}$ in the form of Araxá rock phosphate, applied when the experiment was installed. Therefore, the statistical design consisted of random blocks, organized as a $2 \times 2 \times 4$ factorial array, in split-plots, where residue management and sampling depth were, respectively, the subplot and the sub-subplot.

In the second assay, treatments corresponded to the combination of three factors: control - no cover, $A$. 
pintoi, $P$. phaseoloides and $M$. atropurpureum, rates of $\mathrm{P}$ (0 and $88 \mathrm{~kg} \mathrm{ha}^{-1}$, in the form of Araxá rock phosphate) and residue management (maintenance or removal of residue after each cut). Thus, the design consisted of random blocks organized as a $4 \times 2 \times 2$ factorial array in split-plots, where the subplot was formed based on the management of the aerial part residues. Soil sampling was carried out at a depth between 0 and $10 \mathrm{~cm}$.

Soil samples were taken in March and May, 1998, approximately 36 and 38 months after installation of the main experiment, corresponding respectively to assays 1 and 2, which were homogenized to form compound samples, then immediately passed through a $2 \mathrm{~mm}$ mesh sieve.

The determination of microbial $\mathrm{C}, \mathrm{N}$ and $\mathrm{P}$ contents in the soil followed the fumigation-extraction principle. Microbial $\mathrm{C}$ and $\mathrm{N}$ were extracted simultaneously (De-Polli \& Guerra, 1999). The methodology described by Vance et al. (1987) and Tate et al. (1988) was adopted to quantify C, and, for microbial $\mathrm{N}$, the procedure described by Brookes et al. (1985) was employed, using $50 \mathrm{~mL} \mathrm{~K}_{2} \mathrm{SO}_{4} 0.5 \mathrm{~mol} \mathrm{~L}^{-1}$ as the extractor for each $20 \mathrm{~g}$ of the sample with at actual water content.

The microbial $P$ content was determined according to Brookes et al. (1982) and McLaughlin et al. (1986), with a modification of the soil:solution ratio (Guerra et al., 1995). The used extractor was, for each $10 \mathrm{~g}$ of soil, $100 \mathrm{~mL} \mathrm{NaHCO}{ }_{3} 0.5 \mathrm{~mol} \mathrm{~L}^{-1}$ (pH corrected to 8.5). Part of the filtered extract was submitted to the quantification of total labile $\mathrm{P}(\mathrm{Ptl})$, and $\mathrm{P}$ was determined as described by Braga \& Defelipo (1974).

Soil microbial $\mathrm{C}, \mathrm{N}$ and $\mathrm{P}$ were calculated based on the differences in the amounts of these elements in the fumigated and non-fumigated extracts, and correction factors were later utilized in relation to the recovery efficiency for each of these elements (De-Polli \& Guerra, 1999). Calculations of soil microbial $C, N$ and $P$ contents were made considering oven dried soil at $105^{\circ} \mathrm{C}$.

Some relations between quantified variables were calculated in order to make inferences on the quality of soil organic matter as expressed by the relation microbial $\mathrm{C}$ and organic $\mathrm{C}$ in the soil $(\mathrm{Cm} / \mathrm{C})$, and the efficiency of the microbial biomass in immobilizing $\mathrm{C}$ or $\mathrm{N}(\mathrm{Cm} / \mathrm{Nm})$, as reported by Gama-Rodrigues (1999), or $\mathrm{P}(\mathrm{Cm} / \mathrm{Pm})$ according to Paul \& Clark (1996).

The total organic carbon was quantified according to EMBRAPA (1997). The water soluble (Csag) and available (Cdisp) carbon were obtained with the use of water (Mendonça, 1992) and $\mathrm{NaHSO}_{4} 0.05 \mathrm{~mol} \mathrm{~L}^{-1}$ as extractors, respectively (Medeiros \& Mendonça, 1994), using a soil:extractor ratio of $1: 2$. After agitation and filtration of the extract, both carbon fractions were quantified by colorimetry preconized by Bartlett \& Ross (1988).

The quantification of mineralizable $\mathrm{C}$ (Cmin) was made as proposed by Duda et al. (1999). According to these authors, mineralizable $\mathrm{C}$ corresponds to the fraction of $\mathrm{C}$ that is rapidly utilized by soil microorganisms, as measured by the evolution of $\mathrm{CO}_{2}$ in a 15-day period.

In the second assay, in addition to the variables previously quantified, total nitrogen in the soil $(\mathrm{N})$ (Bremner, 1965) and light organic matter (Mol), were determined according to Anderson \& Ingran (1989).

Pol was obtained according to Bowman \& Cole (1978) by using $5 \mathrm{~g}$ of soil and $100 \mathrm{~mL}$ of $\mathrm{NaHCO}_{3} 0.5$ $\mathrm{mol} \mathrm{L}^{-1}$ (pH adjusted to 8.5). Part of the extract was used to quantify total labile $\mathrm{P}(\mathrm{Ptl})$ and the other part for inorganic labile P (Pil) as described by Duda (2000). The quantification of $P$ in the solution was performed according to Braga \& Defelipo (1974). Pol was obtained by the difference between labile Ptl and Pil.

The means of qualitative factors (species, management and phosphorus) were compared by the Tukey test at $5 \%$ and the coefficients of correlation at 5 $\%$. For the first assay, the variable soil depth was submitted to regression analysis when the effect was significant. The criterion utilized for choosing the best model was the significance of the equation parameters and the adjusted coefficient of determination.

\section{RESULTS AND DISCUSSION}

\section{Assay 1}

Soil depth did not have any effect over the other variables (Table 1). Microbial $\mathrm{C}$ is quoted as an example, in spite of the fact that some authors report that it decreased with depth (Paul \& Clark, 1996; Marchiori Jr \& Melo, 1999).

For variables of which differences were detected there was no uniformity in the type of response. The soil total organic carbon $(\mathrm{C})$ decreased with depth increase (Figure $1 \mathrm{~A}$ ), as it is normally observed in most soils.

The variables microbial $\mathrm{P}$ and $\mathrm{N}$ (Figure $1 \mathrm{~B}$ and C), available (Cdisp) and water soluble C (Csag) (Figure $2 \mathrm{~A}$ and $\mathrm{B}$ ) presented also decreasing values with soil depth. The same tendency was observed for mineralizable $\mathrm{C}$ (Cmin) (Figure $2 \mathrm{C}$ ).

Labile Pt (Figure 2 D) decreased with depth for the two evaluated legume species evaluated. For the soil covered with $M$. atropurpureum the decrease was lower than for the soil covered with $A$. pintoi. This difference could be due to the fact that $A$. pintoi has a broader root distribution at soil surface (Perin et al., 1999) while $M$. atropurpureum has a uniform distribution in depth. Even presenting a more pronounced decrease in labile $\mathrm{Pt}, A$. pintoi had a higher content of this element for all sampled depths, as compared to $M$. atropurpureum.

The Pol/Ptl ratio increased with depth (Figure 3 A). Despite the fact that this ratio has been utilized as an index for phosphate fertilization (Guggenberger et al., 1996), in the present case the observed increase is due to the decrease in Ptl. Since Pol does not change, an increase in the Pol/Ptl ratio occurs. 
Table 1 - Effect of soil depth on soil attributes.

\begin{tabular}{|c|c|c|c|c|c|}
\hline \multirow{2}{*}{ Characteristics } & \multicolumn{5}{|c|}{ Depth $(\mathrm{cm})$} \\
\hline & $0-2.5$ & $2.5-5.0$ & $5.0-10.0$ & $10.0-20.0$ & CV (\%) \\
\hline $\mathrm{Cm}$ (mg kg${ }^{1}$ of soil) & 356.79 & 399.09 & 409.29 & 346.35 & 23.6 \\
\hline $\mathrm{Nm}^{*}$ (mg kg-1 of soil) & 95.54 & 82.63 & 71.11 & 62.08 & 22.8 \\
\hline $\mathrm{Pm}^{*}$ (mg $\mathrm{kg}^{-1}$ of soil) & 15.16 & 11.47 & 10.23 & 8.68 & 29.4 \\
\hline $\mathrm{C}^{*}$ (g kg $\mathrm{kg}^{-1}$ of soil) & 11.92 & 10.65 & 9.76 & 8.38 & 6.5 \\
\hline Csag* $^{*}$ (mg kg-1 of soil) & 82.38 & 62.83 & 51.96 & 42.58 & 10.3 \\
\hline Cdisp* (mg kg-1 of soil) $^{*}$ & 234.9 & 222.95 & 218.56 & 215.92 & 8.2 \\
\hline $\mathrm{Cmin}^{*}$ (mg $\mathrm{kg}^{1}$ of soil) & 390.23 & 335.73 & 275.87 & 243.42 & 20.3 \\
\hline Pil (mg kg-1 of soil) & 7.53 & 6.02 & 4.86 & 4.29 & 17.6 \\
\hline $\mathrm{Ptl}^{*}$ (mg kg-1 of soil) & 11.61 & 10.76 & 10.01 & 8.51 & 8.8 \\
\hline Pol (mg kg ${ }^{1}$ of soil) & 4.08 & 4.74 & 5.15 & 4.22 & 28.5 \\
\hline 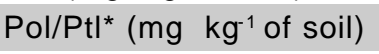 & 35.65 & 43.53 & 51.94 & 49.43 & 23.1 \\
\hline $\mathrm{Cm} / \mathrm{Nm}^{*}$ & 4.08 & 5.11 & 6.06 & 5.85 & 33.5 \\
\hline $\mathrm{Cm} / \mathrm{Pm}^{*}$ & 26.47 & 36.69 & 46.03 & 46.55 & 46.6 \\
\hline $\mathrm{Cm} / \mathrm{C}^{*}(\%)$ & 3.01 & 3.77 & 4.21 & 4.24 & 24.9 \\
\hline
\end{tabular}

$\mathrm{Cm}, \mathrm{Nm}$ and $\mathrm{Pm}$-microbial carbon, nitrogen and P; C - Soil organic carbon; Csag - water soluble carbon; Cdisp - available carbon; Cmin - mineralizable carbon; Pil, Pol and Ptl - labile inorganic, organic and total P; Po/Pt - ratio between labile Pol and Ptl; Cm/ $\mathrm{Nm}$, $\mathrm{Cm} / \mathrm{Pm}$ and $\mathrm{Cm} / \mathrm{C}$ - ratios, respectively, between $\mathrm{Cm}$ and $\mathrm{Nm}, \mathrm{Cm}$ and $\mathrm{Pm}$, and $\mathrm{Cm}$ with soil organic C. Significant at $10 \%$ by $\mathrm{F}$ test.
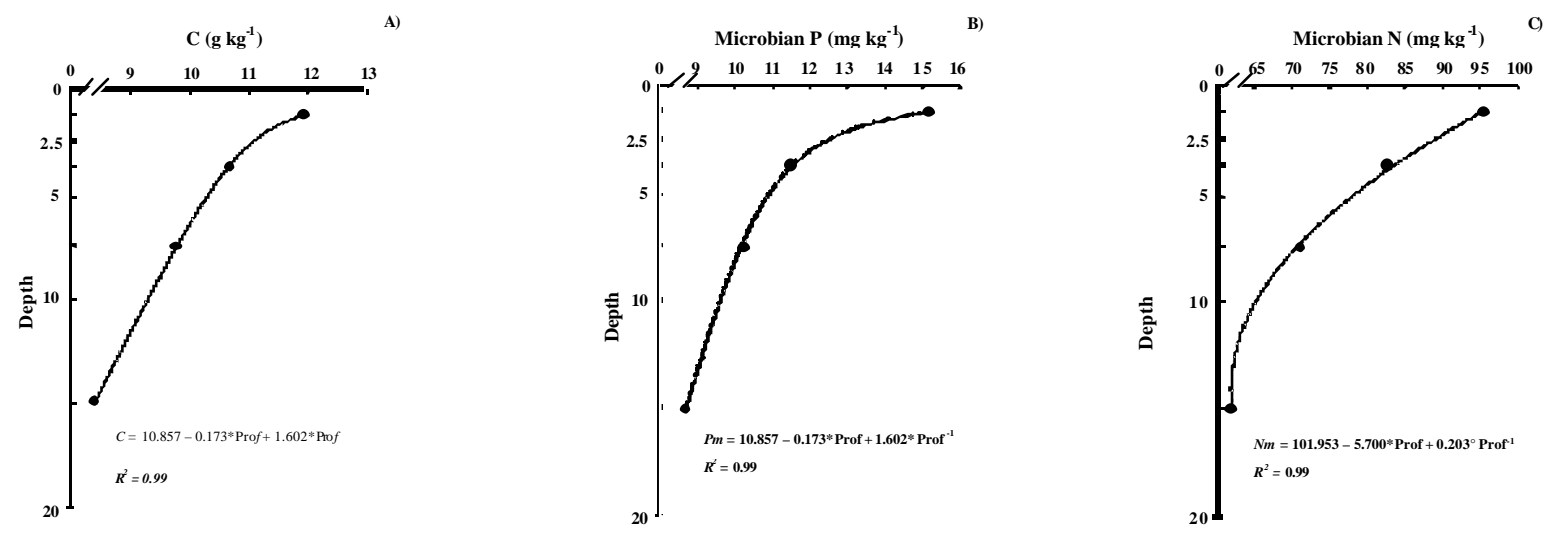

Figure 1 - Variation in total organic carbon (A), microbial $\mathrm{P}(\mathrm{B})$ and $\mathrm{N}(\mathrm{C})$ with soil depth. ${ }^{*}$ and ${ }^{\circ}$ significant, respectively at 5 and $10 \%$.
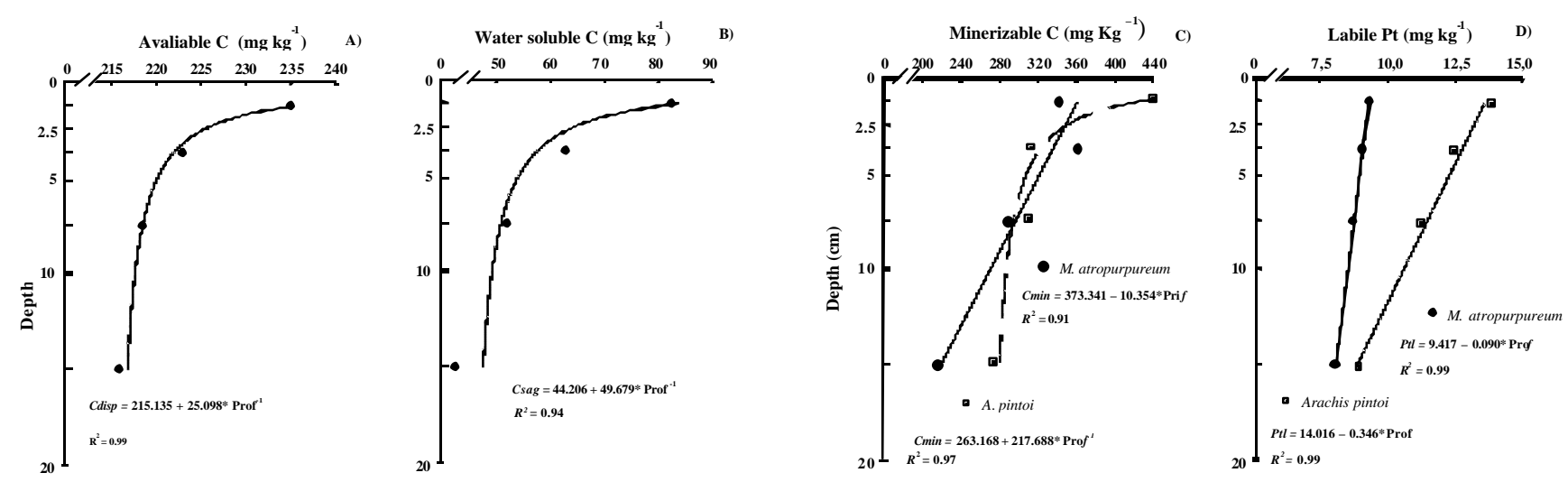

Figure 2 - Variation in contents of available $(A)$, water soluble $(B)$ and mineralizable $C(C)$ and total labile $P(D)$ as a function of soil depth.

Ratios $\mathrm{Cm} / \mathrm{Nm}$ (Figure $3 \mathrm{~B}$ ) and $\mathrm{Cm} / \mathrm{Pm}$ (Figure $3 \mathrm{C})$ increased with soil depth. The increase in these ratios indicates that there is an increase in microorganism efficiency as they immobilize more carbon with the increase in soil depth. Similar results were reported by Paul \& Clark (1996).

The $\mathrm{Cm} / \mathrm{C}$ ratio is utilized to indicate the capacity of accumulating carbon in the microbial 
biomass relative to the soil total organic C (Sparling, 1992; Gama-Rodrigues, 1997), and is therefore useful to detect its variations in the soil. In this study, the $\mathrm{Cm} /$ $C$ ratio increased with soil depth (Figure $3 \mathrm{D}$ ). This result could suggest that there is an increase in $\mathrm{Cm}$ participation relative to the soil organic $\mathrm{C}$, with its increase in depth. However, this is not true considering that, in the present case, the soil organic carbon decreases in depth, increasing the ratio. Using this ratio is important, but one must consider that this variable is influenced by the content and mineralogy of the clay fraction and by vegetation (Sparling, 1992). Thus, the application of this index must be restricted to the same soil type, cultivation system (Gregorich et al., 1994) and, according to the results of this research, soil depth.

The effect of species utilized and management of shoot residues was not verified for most analyzed variables. However, the microbial $\mathrm{N}$ presented greater content in the soil covered with $M$. atropurpureum than with $A$. pintoi (Table 2). With respect to the management of shoot residues after each cut, the effect was detected only for $\mathrm{Nm}$. In this case, maintaining the residues after the cut lead to a greater value as compared to their removal (Table 3).

\section{Assay 2}

The addition of $P$ in the form of natural phosphate $\left(88 \mathrm{~kg} \mathrm{ha}^{-1}\right)$, promoted an increase of $29.5 \%$ in microbial $\mathrm{P}$ when compared to the treatment without phosphate fertilization (Duda, 2000). This result indicates that the soil microbial biomass was able to utilize the $\mathrm{P}$ added in the form of natural phosphate.

There was an effect of management of the aerial part of the plants on $\mathrm{Cm}, \mathrm{Nm}$, Csag, total $\mathrm{N}, \mathrm{C}$ and the $\mathrm{Cm} / \mathrm{C}$ ratio. Maintaining the shoot residues, in comparison to their removal, resulted in higher values for the variables mentioned above, (Table 4).

Maintaining the residues of after each cut was important to sustain a higher microbial activity, conservation of soil organic matter and a better quality
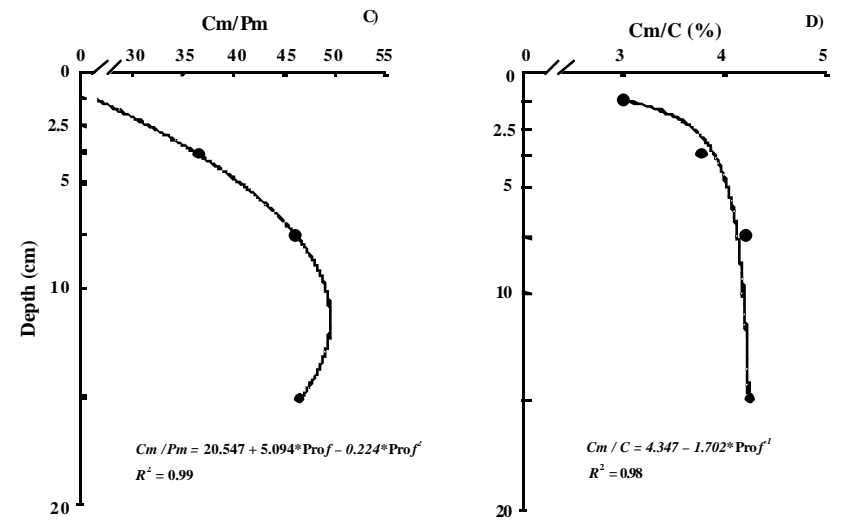

Figure 3 - Variation of ratios Pol/Ptl (A), $\mathrm{Cm} / \mathrm{Nm}(\mathrm{B}), \mathrm{Cm} / \mathrm{Pm}(\mathrm{C})$ and $\mathrm{Cm} / \mathrm{C}(\mathrm{D})$ as a function of soil depth.

Table 2 - Effect of legume species on soil attributes.

\begin{tabular}{|c|c|c|c|}
\hline & \multicolumn{3}{|c|}{ Especies } \\
\hline & A. pintoi & M. atropurpureum & $\mathrm{CV}(\%)$ \\
\hline $\mathrm{Cm}$ (mg kg ${ }^{1}$ of soil) & 339.14 & 416.62 & 11.8 \\
\hline $\mathrm{Nm}^{*}$ (mg kg-1 of soil) & 67.78 & 87.91 & 8.8 \\
\hline Pm (mg kg-1 of soil) & 11.19 & 11.57 & 10.3 \\
\hline $\mathrm{C}$ (g kg-1 of soil) & 10.32 & 10.04 & 5.7 \\
\hline Csag (mg kg-1 of soil) & 58.04 & 61.83 & 6.1 \\
\hline Cdisp (mg kg of soil) & 225.41 & 220.76 & 3.2 \\
\hline Cmin (mg $\mathrm{kg}^{-1}$ of soil) & 332.03 & 290.6 & 4.7 \\
\hline Pil (mg kg-1 of soil) & 6.76 & 4.59 & 11.8 \\
\hline Ptl (mg kg-1 of soil) & 11.64 & 8.8 & 4.4 \\
\hline Pol (mg kg ${ }^{1}$ of soil) & 4.88 & 4.21 & 12.5 \\
\hline Po/Pt (\%) & 42.73 & 47.55 & 11.5 \\
\hline $\mathrm{Cm} / \mathrm{Nm}$ & 5.39 & 5.16 & 3.3 \\
\hline $\mathrm{Cm} / \mathrm{Pm}$ & 35.2 & 42.67 & 13.5 \\
\hline $\mathrm{Cm} / \mathrm{C}$ & 3.31 & 4.3 & 13.7 \\
\hline
\end{tabular}

$\mathrm{Cm}, \mathrm{Nm}$ and $\mathrm{Pm}$-microbial carbon, nitrogen and P; C - Soil organic carbon; Csag - water soluble carbon; Cdisp - available carbon; Cmin - mineralizable carbon; Pil, Pol and Ptl - labile inorganic, organic and total P; Po/Pt - ratio between labile Pol and Ptl; $\mathrm{Cm} / \mathrm{Nm}$, $\mathrm{Cm} / \mathrm{Pm}$ and $\mathrm{Cm} / \mathrm{C}$ - ratios , respectively, between $\mathrm{Cm}$ and $\mathrm{Nm}, \mathrm{Cm}$ and $\mathrm{Pm}$, and $\mathrm{Cm}$ with soil organic C. Significant at $10 \%$ by $\mathrm{F}$ test. 
Table 3 - Effect of management of the aerial part of the plants after cutting on soil attributes.

\begin{tabular}{|c|c|c|c|}
\hline & \multicolumn{3}{|c|}{ Plant residue management } \\
\hline & Maintainance & Removal & CV (\%) \\
\hline $\mathrm{Cm}$ (mg kg${ }^{1}$ of soil) & 370.55 & 385.21 & 13.9 \\
\hline $\mathrm{Nm}^{*}$ (mg kg-1 of soil) & 81.09 & 74.59 & 5.6 \\
\hline Pm (mg kg-1 of soil) & 11.79 & 10.98 & 7.4 \\
\hline C (g kg-1 of soil) & 10.33 & 10.02 & 5.9 \\
\hline Csag (mg kg-1 of soil) & 61.33 & 58.54 & 7.1 \\
\hline Cdisp (mg kg-1 of soil) & 222.78 & 223.39 & 3.8 \\
\hline Cmin (mg kg ${ }^{1}$ of soil) & 322.68 & 299.94 & 13.1 \\
\hline Pil (mg kg-1 of soil) & 5.92 & 5.42 & 7.4 \\
\hline Ptl (mg kg-1 of soil) & 10.38 & 10.07 & 8.5 \\
\hline Pol (mg kg ${ }^{1}$ of soil) & 4.45 & 4.64 & 13.1 \\
\hline $\mathrm{Po} / \mathrm{Pt}(\%)$ & 43.65 & 46.63 & 6.0 \\
\hline $\mathrm{Cm} / \mathrm{Nm}$ & 5.06 & 5.49 & 12.7 \\
\hline $\mathrm{Cm} / \mathrm{Pm}$ & 36.64 & 41.23 & 10.1 \\
\hline $\mathrm{Cm} / \mathrm{C}$ & 3.63 & 3.98 & 10.8 \\
\hline
\end{tabular}

$\mathrm{Cm}, \mathrm{Nm}$ and Pm -microbial carbon, nitrogen and P; C - Soil organic carbon; Csag - water soluble carbon; Cdisp - available carbon ; $\mathrm{Cmin}$ - mineralizable carbon; Pil, Pol and Ptl - labile inorganic, organic and total P; $\mathrm{Po} / \mathrm{Pt}$ - ratio between labile Pol and Ptl; $\mathrm{Cm} / \mathrm{Nm}, \mathrm{Cm} /$ $\mathrm{Pm}$ and $\mathrm{Cm} / \mathrm{C}$ - ratios, respectively, between $\mathrm{Cm}$ and $\mathrm{Nm}, \mathrm{Cm}$ and $\mathrm{Pm}$, and $\mathrm{Cm}$ with soil organic $\mathrm{C}$. Significant at $10 \%$ by $\mathrm{F}$ test.

Table 4 - Effect of management of the aerial part of the plants after cutting on soil attributes.

\begin{tabular}{|c|c|c|c|}
\hline & \multicolumn{3}{|c|}{ Plant residue management } \\
\hline & Maintainance & Removal & CV (\%) \\
\hline$\overline{\mathrm{Cm}^{*}\left(\mathrm{mg} \mathrm{kg}^{-1} \text { of soil }\right)}$ & 262.8 & 229.9 & 17.6 \\
\hline $\mathrm{Nm}^{*}$ (mg kg ${ }^{1}$ of soil) & 46.9 & 43.9 & 11.9 \\
\hline $\mathrm{Pm}$ (mg kg ${ }^{1}$ of soil) & 8.9 & 8.8 & 43.3 \\
\hline $\mathrm{C}^{*}\left(\mathrm{~g} \mathrm{~kg}^{-1}\right.$ of soil) & 14.8 & 14.3 & 2.8 \\
\hline Mol ( $\mathrm{g} \mathrm{kg}^{1}$ of soil) & 0.9 & 0.8 & 36.9 \\
\hline $\mathrm{N}^{*}\left(\mathrm{~g} \mathrm{~kg}^{-1}\right.$ of soil) & 1.0 & 0.9 & 6.9 \\
\hline $\mathrm{Csag}^{*}$ (mg kg-1 of soil) & 31.4 & 27.3 & 26.6 \\
\hline Cdisp (mg kg-1 of soil) & 176.9 & 174.7 & 5.5 \\
\hline Cmin (mg kg-1 of soil) & 262.5 & 270.2 & 16.7 \\
\hline Pil (mg kg ${ }^{1}$ of soil) & 2.9 & 3.3 & 36.7 \\
\hline Ptl (mg kg ${ }^{1}$ of soil) & 10.6 & 10.1 & 14.7 \\
\hline Pol (mg kg-1 of soil) & 7.7 & 6.9 & 22.3 \\
\hline $\mathrm{Po} / \mathrm{Pt}(\%)$ & 73.1 & 68.1 & 13.1 \\
\hline U (\%) & 13.5 & 13.2 & 11.4 \\
\hline $\mathrm{PH}$ & 4.9 & 4.9 & 2.3 \\
\hline $\mathrm{C} / \mathrm{N}$ & 14.1 & 14.2 & 12.7 \\
\hline $\mathrm{Cm} / \mathrm{Nm}$ & 5.9 & 5.4 & 115.7 \\
\hline $\mathrm{Cm} / \mathrm{Pm}$ & 35.3 & 30.3 & 65.2 \\
\hline $\mathrm{Cm} / \mathrm{C}$ & 1.9 * & 1.8 & 23.8 \\
\hline
\end{tabular}

of the material added to the soil, as evidenced previously in many papers (Ocio et al., 1991; Singh \& Singh, 1993; Jensen et al., 1997; Goyal et al., 1999).

Considering the cover utilized, the behavior was distinct with regard to $\mathrm{Cm}$, presenting a higher value for $A$. pintoi and smaller values for the treatment without cover (control), which was not different from $P$. phaseoloides and M. atropurpureum (Table 5).

The effect of legumes on the $\mathrm{Nm}$ content in the soil was distinct in relation to that observed for $\mathrm{Cm}$. In this case, $M$. atropurpureum presented the highest value, with $P$. phaseoloides and $A$. pintoi situated in the intermediate range, and the control having the lowest value (Table 5). Results of residue decomposition rates of $A$. pintoi, P. phaseoloides and M. atropurpureum, indicate that the first species has a higher decomposition rate than the others (Espíndola et al., 1998b).

Thus, the increase in microbial population, indicated by the greater value of $\mathrm{Cm}$ observed for $A$. pintoi, causes the $\mathrm{N}$ contents in the microbial biomass to show a tendency to be smaller, possibly due to the mineralization of $\mathrm{N}$. In the case of $M$. atropurpureum the opposite occurs since it has a higher resistance to decomposition, the $\mathrm{N}$ in the microbial biomass remains for longer time, indicating a higher utilization of $\mathrm{N}$ in the soil by the microorganisms.

The Pm content varied with the type of cover, and $A$. pintoi had the highest value when compared to $M$. atropurpureum and P. phaseoloides (Table 5). The presence of a cover caused a reduction in labile $\mathrm{Pi}$ regardless of the species (Table 5). The highest Pil value was found for the control, followed by $A$. pintoi, $M$. atropurpureum and $P$. phaseoloides, with the smallest values. Pol did not suffer variations as a consequence of plant cover, suggesting that the labile organic compartment is not undergoing depletion, or the Pol synthesis rate is similar to that of mineralization. With respect to labile $\mathrm{Pt}$, the highest values were observed for the control treatment and $A$. pintoi, and the lowest were observed for the other species. These observations thus justify the higher Pm content observed for the soil without cover (control) and covered with $A$. pintoi. It is possible that legumes $M$. atropurpureum and $P$. phaseoloides possess a higher $\mathrm{P}$ absorption capacity than $A$. pintoi, causing the Ptl and Pm rates, in these treatments, to be lower than in the others. 
Table 5 - Effect of legume species on soil attributes.

\begin{tabular}{|c|c|c|c|c|c|}
\hline & \multicolumn{5}{|c|}{ Species } \\
\hline & Controle & A. pintoi & M. atropurpureum & P. phaseoloides & CV (\%) \\
\hline $\mathrm{Cm}$ (mg kg-1 of soil) & $243.9 b$ & $324.5 \mathrm{a}$ & $203.1 \mathrm{~b}$ & $213.7 b$ & 36.5 \\
\hline $\mathrm{Nm}$ (mg kg-1 of soil) & $36.2 \mathrm{c}$ & $44.2 \mathrm{~b}$ & $55.9 \mathrm{a}$ & $45.4 \mathrm{~b}$ & 12.0 \\
\hline $\mathrm{Pm}$ (mg kg-1 of soil) & $9.1 \mathrm{~b}$ & $10.8 \mathrm{a}$ & $7.6 \mathrm{c}$ & $7.9 \mathrm{c}$ & 29.6 \\
\hline$C\left(\mathrm{~g} \mathrm{~kg}^{-1}\right.$ of soil) & 12.6 & 15.9 & 16.6 & 13.0 & 21.9 \\
\hline Mol ( $\mathrm{g} \mathrm{kg}^{-1}$ of soil) & 0.9 & 1.0 & 0.7 & 1.0 & 35.4 \\
\hline $\mathrm{N}$ (g kg-1 of soil) & $1.0 \mathrm{ab}$ & $1.1 \mathrm{a}$ & $0.9 \mathrm{~b}$ & $0.9 \mathrm{~b}$ & 5.6 \\
\hline Csag (mg kg-1 of soil) & $18.6 \mathrm{~b}$ & $34.3 \mathrm{a}$ & $34.9 \mathrm{a}$ & $29.5 \mathrm{a}$ & 17.7 \\
\hline Cdisp (mg kg-1 of soil) & $172.0 \mathrm{bc}$ & $188.6 \mathrm{a}$ & $161.8 \mathrm{c}$ & $180.8 a b$ & 7.4 \\
\hline Cmin (mg kg-1 of soil) & $245.4 b$ & $291.1 \mathrm{a}$ & $288.4 \mathrm{a}$ & $240.4 b$ & 13.2 \\
\hline Pil (mg kg-1 of soil) & $4.6 \mathrm{a}$ & $3.2 \mathrm{~b}$ & $2.4 \mathrm{~b}$ & $2.2 b$ & 17.9 \\
\hline Ptl (mg kg-1 of soil) & $11.9 \mathrm{a}$ & $11.1 \mathrm{ab}$ & $8.9 \mathrm{c}$ & $9.6 \mathrm{bc}$ & 10.1 \\
\hline Pol (mg kg-1 of soil) & 7.3 & 7.9 & 6.5 & 7.4 & 14.4 \\
\hline Pol/Ptl (\%) & $61.9 \mathrm{~b}$ & $71.4 \mathrm{ab}$ & $72.4 \mathrm{a}$ & $76.8 \mathrm{a}$ & 7.5 \\
\hline$U(\%)$ & $11.9 \mathrm{~b}$ & $12.3 \mathrm{~b}$ & $14.6 \mathrm{a}$ & $14.9 \mathrm{a}$ & 11.3 \\
\hline $\mathrm{pH}$ & $4.8 \mathrm{~b}$ & $4.7 b$ & $5.5 \mathrm{a}$ & $4.8 b$ & 2.8 \\
\hline $\mathrm{C} / \mathrm{N}$ & $12.1 \mathrm{~b}$ & $13.8 \mathrm{~b}$ & $16.8 \mathrm{a}$ & $13.2 \mathrm{~b}$ & 17.8 \\
\hline $\mathrm{Cm} / \mathrm{Nm}$ & 6.7 & 7.5 & 3.6 & 4.9 & 104.5 \\
\hline $\mathrm{Cm} / \mathrm{Pm}$ & 30.3 & 41.6 & 28.5 & 30.8 & 44.7 \\
\hline $\mathrm{Cm} / \mathrm{C}$ & 2.1 & 2.1 & 1.5 & 1.9 & 29.8 \\
\hline
\end{tabular}

Means followed by a common letter, between columns, do not differ by Tukey test at $5 \%$.

The three perennial herbaceous legume species presented identical Csag values, higher than the treatment without plant cover (Table 5). With regard to Cdisp, the species standing out were $A$. pintoi and $P$. phaseoloides (Table 5). For Cmin, however, the soil covered with $A$. pintoi and $M$. atropurpureum had the highest values. The species caused distinct effects on carbon compartmentalization. The three evaluated species proved efficient in raising the Csag levels. This is important due to the fact that this fraction of soil total organic $\mathrm{C}$ corresponds to a source of energy that is easily available to soil microorganisms, since it is formed essentially of compounds of aliphatic nature (Liang et al., 1996; Liang et al., 1998).

In the case of Cdisp, since the species behaved distinctly in relation to this fraction, it can be suggested that, somehow, $A$. pintoi and $P$. phaseoloides are efficient in both increasing Csag and Cdisp, as compared to $M$. atropurpureum. Observations relative to the "in situ" decomposition rates for these legumes, under similar edaphic and climatic conditions, denote that $A$. pintoi has a lower resistance to decomposition as compared to $M$. atropurpureum (Espíndola et al., 1998b). Therefore, the greater resistance of $M$. atropurpureum to decomposition, can make the product of transformation of its residues to be sufficient only to maintain Csag, differently than $A$. pintoi and $P$. phaseoloides. For the soil total nitrogen $(\mathrm{N})$, $A$. pintoi was prominent, since it surpassed $M$. atropurpureum and $P$. phaseoloides (Table 5).
The plant cover type did not affect the $C$ total organic content, but the $\mathrm{C} / \mathrm{N}$ ratio was affected. The soil covered with $M$. atropurpureum presented the highest $\mathrm{C} /$ $\mathrm{N}$ ratio. The other treatments were equivalent among themselves, having the smallest values (Table 5). Similar behavior was observed for soil $\mathrm{pH}$, with $M$. atropurpureum being prominent, since it had a $\mathrm{pH}$ that was higher than all other treatments. A similar effect was obtained for the actual soil water content $(\mathrm{U}), M$. atropurpureum and $P$. phaseoloides presenting the greatest values as compared with the control treatment and the soil covered with $A$. pintoi (Table 5).

$\mathrm{Cm}$ was positively correlated to $\mathrm{Pm}$, labile $\mathrm{Pt}$ and labile $\mathrm{Po}$ (Table 6). From the results presented, $\mathrm{Cm}$ does not depend on soil organic $\mathrm{C}$, as it seems to be more likely associated to organic compounds produced by the root system. Nm had negative correlations with Ptl and Pil, indicating that these variables inhibit the accumulation of $\mathrm{N}$ in the microbial biomass. For Csag, Cmin and $\mathrm{C} / \mathrm{N}$ the correlation was positive, suggesting that these variables provide a greater immobilization of $\mathrm{N}$ in the microbial tissue. The increase in $\mathrm{P}$ content in the microbial biomass increased with the increase in Ptl and Pol, and with Mol (Table 6).

The effect of soil cover with perennial herbaceous legumes on soil characteristics, notably the microbial and available $\mathrm{C}$, varies according to the type of species that is grown. With respect to management of the aerial part of the plants after each cut, it was observed that the 
Table 6 - Coefficients of correlation between variables in assay 2.

\begin{tabular}{llll}
\hline & $\mathrm{Cm}$ & $\mathrm{Nm}$ & $\mathrm{Pm}$ \\
\hline $\mathrm{Nm}$ & -0.21 & & \\
$\mathrm{Pm}$ & $0.68^{*}$ & -0.16 & \\
$\mathrm{Ptl}$ & $0.59^{\star}$ & -0.7 & $0.57^{\star}$ \\
$\mathrm{Pil}$ & 0.23 & $-0.67^{*}$ & 0.34 \\
$\mathrm{Pol}$ & $0.66^{*}$ & -0.34 & $0.50^{*}$ \\
Csag & 0.15 & $0.70^{*}$ & -0.24 \\
Cmin & 0.13 & $0.5^{*}$ & 0.10 \\
$\mathrm{Mol}$ & $0.51^{*}$ & -0.29 & $0.53^{*}$ \\
$\mathrm{~N}$ & $0.62^{*}$ & -0.2 & 0.49 \\
$\mathrm{C}$ & 0.03 & $0.62^{*}$ & 0.10 \\
$\mathrm{C} / \mathrm{N}$ & -0.25 & $0.64^{*}$ & -0.12 \\
\hline
\end{tabular}

Coefficients of correlation significant at $5 \%$.

practice of removing the residues of legumes, for other purposes, has to be re-evaluated, otherwise there could be a negative interference on the characteristics associated to soil fertility.

\section{CONCLUSIONS}

Microbial $\mathrm{C}$ did not vary with soil depth for the $20 \mathrm{~cm}$ layer. On the other hand, there was a decrease in microbial $\mathrm{N}$ and $\mathrm{P}$, water soluble, available, and mineralizable $\mathrm{C}$.

The perennial herbaceous legume species distinctly influenced the variables related to organic carbon in the soil, except for the fraction that is soluble in water. A. pintoi provided an increase in microbial $\mathrm{C}$, as compared to Pueraria phaseoloides and Macroptilium atropurpureum.

Maintaining the aerial part residues of plants after each cut provided increases in microbial $\mathrm{C}$ and $\mathrm{N}$, total organic $\mathrm{C}$ and $\mathrm{N}$, and fractions of organic $\mathrm{C}$ in the soil.

\section{REFERENCES}

ANDERSON, J.M.; INGRAM, J.S.I. Tropical soil biology and fertility: a handbook of methods. Wallingord: C A B International. 1989. 171p.

ANDERSON, T.H.; DOMSCH, K.H. Ratio of microbial biomass to the total organic carbon in arable soils. Soil Biology and Biochemistry, v.21, p.471-479, 1989

BARTLETT, R.J.; ROSS, D.S. Colorimetric determination of oxidizable carbon in acid soil solutions. Soil Science Society of America Journal, v.52, p.1191 - 1192, 1988

BOWMAN, R.A.; COLE, C.V. Transformations of organic phosphorus substrates in soils as evaluated by $\mathrm{NaHCO}_{3}$ extraction. Soil Science, v.125, p.49-54, 1978 .

BRAGA, J.M.; DEFELIPO, B.V. Determinação espectrofotométrica de fósforo em extratos de solos e plantas. Revista Ceres, v.113, p.73-85, 1974.

BREMNER, J.M. Total nitrogen. In: BLACK, C.A. (Ed.) Methods of soil analysis Part 2. Madison: ASA; SSSA, 1965. p.1149-1178. (Agronomy, 9).

BROOKES, P.C.; LANDMAN, A.; PRUDEN, G.; JENKINSON, D.S. Chloroform fumigation and the release of soil nitrogen: a rapid direct extraction method to measure microbial biomass nitrogen in soil. Soil Biology and Biochemistry, v.17, p.837-842, 1985

BROOKES, P.C.; POWLSON, D.S.; JENKINSON, D.S. Measurement of microbial biomass phosphorus in soil. Soil Biology and Biochemistry, v.14, p.319-329, 1982.

CARTER, M.R. The influence of tillage on the proportion of organic carbon and nitrogen in the microbial biomass of medium-textured soils in a humid climate. Biology and Fertility of Soils, v.11, p.135-139, 1991.
COSTANTINI, A.; SEGAT, A.; COSENTINO, D. The effect of different soil managment procedures on carbon cycle components in an entic hapludoll. Communications in Soil Science and Plant Analysis, v.26, p.27612767, 1995.

DALCOMO, J.M. Avaliação de leguminosas perenes para cobertura de solo em pomar cítrico no Município de Jerônimo Monteiro, ES. Itaguaí; 1997. 105p. Dissertação (Mestrado). Universidade Federal Rural do Rio de Janeiro.

DE-POLLI, H.; GUERRA, J.G.M. C, N e P na biomassa microbiana do solo. In: SANTOS, G.A.; CAMARGO, F.A.O., (Ed.) Fundamentos da matéria orgânica do solo: ecossistemas tropicais e subtropicais. Porto Alegre: Genesis, 1999. p.389-411.

DUDA, G.P. Conteúdo de fósforo microbiano, orgânico e biodisponível em diferentes classes de solo. Seropédica; 2000. 158p. Tese (Doutorado). Universidade Federal Rural do Rio de Janeiro.

DUDA, G.P.; CAMPELLO, E.F.C.; MENDONCA, E.S.; LOURES, J.L. DOMINGOS, M. Avaliação de frações da matéria orgânica do solo para caracterização de áreas degradadas. Revista Brasileira de Ciência do Solo, v.23, p.723-728, 1999.

EMPRESA BRASILEIRA DE PESQUISA AGROPECUÁRIA. Manual de métodos de análises de solo. Brasília: EMBRAPA Comunicação para Transferência de Tecnologia; Rio de Janeiro: EMBRAPA, CNPS, 1997. 212p.

ESPÍNDOLA, J.A.A.; GUERRA, J.G.M.; ALMEIDA, D.L. de; TEIXEIRA, M.G. URQUIAGA, S.; BUSQUET, R.N.B.; PERIN, A. Contribuição da cobertura do solo com leguminosas herbáceas perenes para o desenvolvimento inicial da bananeira (Musa spp.) Seropédica: Embrapa, CNPAB, 1998a. 3p. (Pesquisa em Andamento, 10)

ESPÍNDOLA, J.A.; GUERRA, J.G.M.; ALMEIDA, D.L.; TEIXEIRA, M.G.; URQUIAGA, S.; PERIN, A. Decomposição in situ da parte aérea de algumas leguminosas perenes usadas como cobertura viva do solo. In FERT BIO98, Caxambú, 1998. Anais. Caxambú: UFLA/SBCS/SBM, 1998b. p.110.

GAMA-RODRIGUES, E.F. da. Biomassa microbiana e ciclagem de nutrientes. In: SANTOS, G.A.; CAMARGO, F.A.O. (ed.) Fundamentos da matéria orgânica do solo: ecossistemas tropicais e subtropicais. Porto Alegre: Genesis, 1999. p.227-243.

GAMA-RODRIGUES, E.F. da Carbono e nitrogênio da biomassa microbiana do solo e da serrapilheira de povoamentos de eucalipto. Seropédica; 1997. 108p. Tese (Doutorado). Universidade Federal Rural do Rio de Janeiro.

GOYAL, S.; CHANDER, K.; MUNDRA, M.C.; KAPPOR, K.K. Influence of inorganic fertilizers and organic amendments on soil organic matter and soil microbial properties under tropical conditions. Biology and Fertility of Soils, v.29, p.196-200, 1999.

GRANATSTEIN, K.M.; BEZDICEK, D.F.; COCHRAM, V.L.; ELLIOTT, L.F.; HAMMEL, J. Long-term tillage and rotation effects on soil microbial biomass, carbon and nitrogen. Biology and Fertility of Soils, v.5, p.265$270,1987$.

GREGORICH, E.G.; CARTER, M.R.; ANGERS, D.A.; MONREAL, C.M.; ELLERT, B.H. Towards a minimum data set to assess soil organic matter quality in agricultural soils. Canadial Journal of Soil Science, v.74, p.367385, 1994.

GUERRA, J.G.M.; FONSECA, M.C. da; ALMEIDA, D.L. de; DE-POLLI, H.; FERNANDES, M.S. Conteúdo de fósforo da biomassa microbiana de um solo cultivado com Brachiaria decumbens Stapf. Pesquisa Agropecuária Brasileira, v.30, p.543-551, 1995.

GUERRA, J.G.M.; TEIXEIRA, M.G. Avaliação inicial de algumas leguminosas herbáceas perenes para utilização como cobertura viva permanente do solo. Seropédica: EMBRAPA, CNPAB, 1997. 7p. (Comunicado Técnico, 16)

GUGGENBERGER, G.; CHRISTENSEN, B.T; RUBAEK, G.; ZECH, W. Landuse and fertilization effects on $P$ forms in two European soils: resin extraction and ${ }^{31} \mathrm{P}-\mathrm{NMR}$ analysis. European Journal of Soil Science v.47, p.605-614, 1996

INSAN, H.; MITCHELL, C.C.; DORMAAR, J.F. Relationship of soil microbial biomass and activity with fertilization practice and crop yield of three utisols. Soil Biology Biochemistry, v.23, p.459-464, 1991.

JENSEN, L.S.; MUELLER, T.; MAGID, J.; NIELSEN, N.E. Temporal variation of $\mathrm{C}$ and $\mathrm{N}$ mineralization, microbial biomass and extractable organic pools in soil after oilseed rape straw incorporation in the field. Soil Biology and Biochemistry, v.29, p.1043-1055, 1997.

LADD, J.N.; AMATO, M.; LI-KAI, Z.; SHULTZ, J.E. Differential effects of rotation, plant residue and nitrogen fertilizer on microbial biomass and organic matter in an australian alfisol. Soil Biology and Biochemistry, v.26, p.821-831, 1994

LIANG, B.C.; GREGORICH, E.G.; SCHNITZER, M.; VORONEY, P.R. Carbon mineralization in soils of different textures as affected by water-soluble organic carbon extracted form composted dairy manure. Biology and Fertility of Soils, v.21, p.10-16, 1996.

LIANG, B.C.; MacKENZIE, A.F; SCHNITZER, M.; MONREAL, C.M.; VORONEY, P.R.; BEYAERT, R.P. Management-induced change in labile soil organic matter under continous corn in eastern Canadian soils. Biology and Fertility of Soils, v.26, p.88-94, 1998. 
LINN, D.M.; DORAN, J.W. Aerobic and anaerobic microbial populations in no-till and plowed soils. Soil Science Society of America Journal, v.48, p.794-799, 1984.

MARCHIORI Jr., M.; MELO, W.J. Carbono, carbono da biomassa microbiana e atividade enzimática em um solo sob mata natural, pastagem e cultura do algodoeiro. Revista Brasileira de Ciência do Solo, v.23, p.257-263, 1999.

McLAUGHLIN, M.J; ALSTON, A.M.; MARTIN, J.K. Measurement of phosphorus in the soil microbial biomass: a modified procedure for field soils. Soil Biology and Biochemistry, v.18, p.437-443, 1986.

MEDEIROS, M.L. \& MENDONCA, E.S. Matéria orgânica lábil e sua relação com elementos trocáveis de solos com diferentes mineralogia. Textura e teor de matéria orgânica. Viçosa: Universidade Federal de Viçosa, 1994. 24p. (Relatório. PIBIC/CNPq)

MENDONCA, E.S. The effect of the organic and mineral fractions on the acidity and charge of soils from the cerrado region. Brazil. Reading; 1992. 230p. Thesis (PhD). University of Reading.

MONEGAT, C. Plantas de cobertura do solo: características e manejo em pequenas propriedades. Chapecó: Ed. do autor, 1991, 337p.

OCIO, J.A.; BROOKES, P.C.; JENKINSON, D.S. Field incorporation of straw and its effects on soil microbial biomass and soil inorganic N.Soil Biology and Biochemistry, v.23, p.171-176, 1991

PAUL, E.A.; CLARK, F.E. Soil microbiology and biochemistry. San Diego: Academic Press, 1996. 340p.

PERIN, A.; GUERRA, J.G.M.; TEIXEIRA, M.G. Avaliação preliminar da densidade de plantas sobre o crescimento e estoque de nutrientes de duas leguminosas herbáceas perenes usadas como cobertura permanente do solo. Seropédica: EMBRAPA, CNPAB, 1998. 3p. (Pesquisa em Andamento, 9).

PERIN, A.; LIMA, E. A.; PEREIRA, M. G.; TEIXEIRA, M. G.; GUERRA, J. G. $M$.; Efeitos de coberturas vivas com leguminosas herbáceas perenes sobre o conteúdo de água do solo durante o período seco. Seropédca: EMBRAPA, CNPAB, 1999. 4P. (Pesquisa em Andamento, 26).

REGANOLD, J.P. Comparation of soil properties as influenced by organic and conventional farming systems. American JouRnal of Alternative Agriculture, v.3, p.144-155, 1988.
SIMEK, M.L.; HOPKINS, D.W.; KALCIK, J.; PICEK, T.; SANTRUCKOVA, H. STANA, J.; TRAVNIK, K. Biological and chemical properties of arable soils affected by long-term organic and inorganic fertilizer applications. Biology and Fertility of Soils, v.29, p.300-308, 1999.

SINGH, J.; SINGH, K.P. Effect of residue placement and chemical fertilizer on soil microbial biomass under tropical dryland cultivation. Biology and Fertility of Soils, v.16, p.275-281, 1993.

SPARLING, G. Ratio of microbial biomass carbon to soil organic carbon as a sensitive indicator of changes in soil organic matter. Australiam Jounal of Soil Research, V, v.30, p.195-207, 1992.

SPARLING, G.; VOJVODIC-VUKOVIC, M.; SCHIPPER, L.A. Hot-watersoluble $C$ as a simple measure of labile soil organic matter: the relationship with microbial biomass C. Soil Biology and Biochemistry, v.30, p.14691472, 1998.

SWEZEY, S.L.; WERNER, M.R.; BUCHANAN, M.; ALLISON, J. Comparation of conventional and organic apple production systems during three years of convertion to organic management in coastal California, American Journal of Alternative Agriculture, v.13, p.162-180, 1998.

TATE, K.R.; ROSS, D.J.; FELTHAM, C.W. A direct extraction method to estimate soil microbial $C$ : effects of experimental variables and some different calibration procedures. Soil Biology and Biochemistry, Oxford, v.20, p.329-335, 1988.

VANCE, E.D.; BROOKS, P.C.; JENKINSON, D.S. An extraction method for measuring soil microbial biomass C. Soil Biology and Biochemistry, v.19, p.703-707, 1987.

VARGAS, L.K.; SCHOLLES, D. Nitrogênio da biomassa microbiana em solo sob diferentes sistemas de manejo, estimado por método de fumigação. Revista Brasileira de Ciência do Solo, v.22, p.411-417, 1998.

WERNER, M.R. Soil quality characteristics during conversion to organic orchard management. Applied Soil Ecology, v.5, p.151-167, 1997.

Received November 29, 2001 